\title{
Book review: \\ Gresh, G. F., \& Keskin, T. (Eds.). (2018). \\ US Foreign Policy in the Middle East from American Missionaries to the Islamic State. New York: Routledge, 326 p.
}

\author{
Wissal Werfelli $\square$, Rodeh Hourieh $\mathbb{D}$ \\ RUDN University, Moscow, Russian Federation \\ \wiswerfelli@gmail.com
}

For citation: Werfelli, W., \& Hourieh, R. (2021). Book review: Gresh, G. F., \& Keskin, T. (Eds.). (2018). US Foreign Policy in the Middle East from American Missionaries to the Islamic State. New York: Routledge, 326 p. Vestnik RUDN. International Relations, 21(3), 587-590. https://doi.org/10.22363/2313-0660-2021-21-3-587-590

\section{Рецензия на книгу: US Foreign Policy in the Middle East from American Missionaries to the Islamic State / Ed. by G.F. Gresh, T. Keskin. New York: Routledge, 2018. 326 p.}

\author{
В. Верфелли $₫$, Р. Хориех \\ Российский университет дружбы народов, Москва, Российская Федерация \\ $\triangle$ wiswerfelli@gmail.com
}

Для цитирования: Werfelli W., Hourieh R. Book review: Gresh, G. F., \& Keskin, T. (Eds.). (2018). US Foreign Policy in the Middle East from American Missionaries to the Islamic State. New York: Routledge, 326 р. // Вестник Российского университета дружбы народов. Серия: Международные отношения. 2021. Т. 21. № 3. C. 587-590. DOI: $10.22363 / 2313-0660-2021-21-3-587-590$

The Middle East has gained a huge importance in the US foreign policy since the second half of the last century. The American foreign policy is affected by a set of constants, the most important of which are the security of Israel and its interests, as well as ensuring the flow of energy resources on international shipping lines within appropriate production levels.

Throughout this edited volume the authors attempt to describe how the US foreign policy has shaped the regional dynamics, and what effect it has had on the broader Middle East during the past decades. In contextualizing the long and complicated relation between the United States and the Middle Eastern countries, in particular with the hegemonic regional actors, the book could give the reader an opportunity to understand the reasons of regional instability.

The book sheds the light on "the prenineteenth-century American perception" of the Middle East in both cultural and economic levels and contextualized the US strategy origins of penetration into the region. Due to the complex nature of the subject resulting from the overlapping of the international and regional system and the struggle of all these structures

(C) Werfelli W., Hourieh R., 2021

This work is licensed under a Creative Commons Attribution 4.0 International License.

https://creativecommons.org/licenses/by/4.0/ 
among themselves, the authors rely on the historical method which has been used in tracing the roots of a structural and systemic analysis and linking them to the final reached result, as well as the descriptive approach. These two methods are considered successful in understanding the international phenomenon by dismantling the relationship between sub-regional and international systems and the complex relationship between regional and international actors and comprehending the influence exerted by the international system on the regional security system in the Middle East. The balance of power theory is used as it's a core tenet of both classical and neorealist theories and seeks to explain alliance formation, maintaining or increasing in power.

Ozlem Madi-Sisman and Cengiz Sisman focus on the special role that got the Middle East for the United States by the early 19th century. The American perception of the region became to change firstly by the vast missionary movement which started in the territory of the Ottoman Empire and stretched across the spectrum of American Protestantism and went into the Islamic world. The "dawn of the millennium" as the Americans called it was considered as a historic turning point in the American foreign policy toward the Middle East (Gresh \& Keskin, 2018, pp. 18-21).

Sean Foley highlights the special US-Saudi relationship from historical and economic point of view, and its impact on the war against ISIS (Gresh \& Keskin, 2018, p. 39).

The second part gives an overview of the challenges that faced Washington in its foreign policy during the Cold War era. Nicolas A. Spencer examines the United States attempts to exploit the geostrategic rivalry between Russia and Turkey in order to minimize the significant and influential role of Russia in the Middle East (Gresh \& Keskin, 2018, pp. 49-50). The US Doctrine of containment concurred with "Turkey's proposed role in bridging the West and the Middle East" has formed a starting point in the USTurkish strategic relationship, setting the stage for Turkey to join NATO (Gresh \& Keskin, 2018, p. 53). This relationship didn't last longer and took its way to rupture due to the Cyprus dispute, second Iraq invasion and the Kurdish Question later (Gresh \& Keskin, 2018, pp. 54-60).

Gökser Gökçay's analysis of the US-Turkish relationship during the Cold War is based on the unpublished American, British and Turkish archival materials to reveal the truth that the American economic and military aid program, known successively as Griddle and Marshall Plans for Turkey under the Truman Doctrine, considered as the key aspect of the US foreign policy, was not in order to preserve the Turkish territorial integrity but was a part of the US containment strategy for the Soviet presence in the Middle East through Turkey as its important ally in the region (Gresh \& Keskin, 2018, pp. 69-75).

Elisabeth Bishop discusses the impact of the US atomic policy, called "atoms for Peace program" (Gresh \& Keskin, 2018, p. 89) toward Hashemite Iraq on the UK-Iraqi privileged relationship, as well as its foreign policy responsibilities in the Arab world.

The book describes the US efforts to balance its opposing powers and strategic alliances in the Middle East region. It underlines the solid USIsraeli alliance due to the common strategic, domestic and ideological share despite some core disagreements including the peace process (Gresh \& Keskin, 2018, p. 112). Jeremy Pressman talks, as well about the significant influence of the Israel Lobby on American foreign policy, especially in the Arab world (Mearsheimer \& Walt, 2007). By the end of the chapter, the author poses questions about the prospects for the bilateral relationship between the two vital allies.

Suleyman Elik, Fatma Asli Kelkitli, and Michael McCall examine the impact of US national security interests on its relations with Middle Eastern regional powers.

Suleyman Elik has studied the historical development of the US-Iranian and US-Turkish relationship, which has been shaped due to the changing dynamics of the international system. The period of 1945-1979 witnessed a significant strategic engagement between Washington and both Tehran and Ankara (Gresh \& Keskin, 2018, pp. 119-121) which did not last. While the 1979 revolution and later the Iranian nuclear ambitions as well as Iran's proxy wars have transformed Iran 
from a "leader proxy" of the U.S. interests in the Persian Gulf to a "negative balancer" (Gresh \& Keskin, 2018, pp. 119-126). The US-Turkish relations continue to decline due to several factors covered by the author in details.

The authors focus on the special relationship between the United States and the Gulf Arab Countries due to their strategic location that must be kept under surveillance. Starting with the US-Qatari relations which were described by the author as an "alliance between a great power and a small state" (Gresh \& Keskin, 2018, p. 139). The authors have studied the bilateral relation from different aspects - military, political, educational and cultural as well.

Michael McCall analyzes the impact of the Obama new "doctrine retrenchment" on the U.S. - GCC partnership which remains the strongest due to the strategic interests. The author argues that the US foreign policy toward the Middle East has been shaped under the Obama's administration which is recognized as a combination of "containment and offshore balancing instead of primacy" (Gresh \& Keskin, 2018 , p. 157). Those changes did not affect the military aspect of the U.S. - GCC cooperation due to American geostrategic concerns in the Gulf area and "the Gulf countries' dependence on external powers to guarantee their defense" (Gresh \& Keskin, 2018, p. 160) as it did with the economic and diplomatic elements.

The last part of the book discusses the impact of the US policy changes in the aftermath of the 9/11 attacks on the Middle Eastern regional instability. Russell A. Burgos discusses in chapter 10, the 2000s Iraq War in a historical context. Furthermore, he argues that the US policymakers never defend a specific policy for the "Iraq problem" (Gresh \& Keskin, 2018, p. 176) but it was subordinated to partisan facts and not to strategic needs, as was the decisions related to subjects of "national interests."

Mohamed Ali Adraoui presents the Arab uprising with a special focus on the Egyptian revolution in 2011 and the relationship between the US and the Muslim Brothers groups re-raised and integrated into the political game. The author sheds light on how the Obama administration policy has dealt with the Islamist movement.
Ahmed Ali Salem focuses on the way how the Obama's administration dealt with the Egyptian revolution despite the contradictions between the first Obama's administration policy marked by significant changes which was balancing between realism and idealism in a theoretical point of view, and the country's statusquo, taking into consideration that "no more important partner in the Arab world than Egypt" (Gresh \& Keskin, 2018, p. 216) from geopolitical and economic point of view.

The historical US-Syrian relationship is discussed by Ethan Corbin since the postwar years when Syria was considered as second-tier concern (Gresh \& Keskin, 2018, p. 227) despite the geostrategic importance to the U.S., due to the confrontation between Washington and the Assad regime accused of sponsoring terrorism add to that the Syrian civil war and the return of Russia to the region.

Hamad H. Albloshi analyses the impact of the Iranian hard-line conservatives' approach and their ambitions to export their revolution on the US Iranian relationship (Gresh \& Keskin, 2018, pp. 246-248). The author argues that Iran's foreign policy has been unstable since the 1979 Islamic revolution despite its confrontation with the international community but has kept the same strategy with both Israel and the U.S.

Kelly Gleason explains the reasons behind the failure of US in dealing with its online counterterrorism messaging to fight against ISIS (Gresh \& Keskin, 2018, p. 262) with a brief overview of its roots and its propaganda.

Tugrul Keskin discusses the fluctuation of the US foreign policy between hard and soft power. President Donald Trump's mandate is characterized by an imbalance and fluctuation in his policies towards domestic files and instability in his foreign policy that appeared to be a prominent sign in the behavior of his administration (Gresh \& Keskin, 2018, pp. 286-288). The author in this chapter realizes how the Trump's administration, on his first year of presidency, was not independent and its foreign policy is influenced by the power elite inside the Beltway (Gresh \& Keskin, 2018, p. 289).

On reading the book one can notice a contradiction between the introduction of the book by Geoffrey F. Gresh hinting that the 
situation of instability and war in the Middle Eastern region is due to the involvement of the United States in the region during decades, and the history told by the authors citing the great importance of the American presence and the significance of the security and economic engagement between the United States and the major actors of the region: Saudi Arabia, Iran, Egypt, Israel including Turkey in order to contain the Soviet Union and then Russia.

Despite the rich historical background in most of the chapters and the successful use of narrative style of the key aspects and turning points which led to draw the U.S. foreign policy features toward the Middle East, the authors tend to bias toward the American supremacy against the Russian presence in the region. while the study was designed to be a critical analysis of the American involvement in the region from the founding fathers to the Trump era trying to find changes between the past U.S. presidents and President Trump policies, reaching the result that multiple actors, institutionalized power holders and interest groups as well as the powerful Israeli lobby are the architects of the US foreign policy, and former President Trump is not as powerful as the interest groups to be able to change the American strategy toward the region.
The authors also emphasize on giving the impression that the withdraw of the United States from the Middle East in the aftermath of the second World War, would have led to "the spread of communism in a newly bipolar world" (Gresh \& Keskin, 2018, p. 1) which represented, according to the co-authors, a 'threat to the regional security', and it's the US to deter the 'Soviet expansion'. The book gave as well, a special attention to the US-Turkish 'common strategic concerns' on explaining the past, describing the present and predicting the future of the dual relationship, despite their crisis-ridden relation.

The focus on the dependence of the Middle Eastern and GCC countries on the American security umbrella could give the impression that the United States is the only responsible power able to maintain the stability of the regional security, while Russia has marked a significant presence in the region as a major power and a "positive balancer" through its active diplomatic strategy and long-standing relationships with a number of Middle Eastern countries dating back centuries, which enables it to remain as an influential actor and a key power in the region.

Поступила в редакцию / Received: 25.03.2021

Принята к публикации / Accepted: 10.06.2021

\title{
References / Библиографический список
}

Gresh, G. F., \& Keskin, T. (Eds.). (2018). US foreign policy in the Middle East from American missionaries to the Islamic State. New York: Routledge.

Mearsheimer, J. J., \& Walt, S. M. (2007). The Israel lobby and US foreign policy. London: Penguin Books.

\begin{abstract}
About the authors: Werfelli Wissal - Postgraduate Student, Department of Theory and History of International Relations, RUDN University; ORCID: 0000-0003-4803-1386; e-mail: wiswerfelli@gmail.com

Hourieh Rodeh - Postgraduate Student, Department of Theory and History of International Relations, RUDN University; ORCID: 0000-0002-2918-7484; e-mail: rodahourie@gmail.com
\end{abstract}

Сведения об авторах: Верфелли Виссаль - аспирантка кафедры теории и истории международных отношений Российского университета дружбы народов; ORCID: 0000-0003-4803-1386; e-mail: wiswerfelli@gmail.com

Хориех Родех - аспирантка кафедры теории и истории международных отношений Российского университета дружбы народов; ORCID: 0000-0002-2918-7484; e-mail: rodahourie@gmail.com 